\title{
APRENDIZAGEM E REPRESENTACÃO. OS ANTROPÓLOGOS E AS APRENDIZAGENS
}

\author{
Alain Pierrot* \\ Université Paris Descartes - França
}

Resumo: Seguindo Boas, muitos antropólogos consideram que os processos de aprendizagem não dizem respeito à sua disciplina e temem que essa temática seja atualmente utilizada pelos cognitivistas para anexar a antropologia à sua psicologia inatista. Depois mostrar que o modelo chomskyano interioriza contraditoriamente o esquema escolar da gramática escrita e que, reduzindo a aprendizagem a seu único "despertar" de representações internas, ele não reconhece, de fato, qualquer pertinência com as atividades reais de aprendizagem; este artigo se concentra nas modalidades de aprendizagem de duas atividades de representação gráfica: a escrita $e$ o desenho. Historicamente, parece que a escrita foi sistemática e violentamente transmitida por domesticação e que o desenho pôde ser proibido, mas não transmitido desse modo porque ele constitui uma maneira de ser globalmente autônoma como toda verdadeira aprendizagem. O desenho é sempre bem mais que uma representação mental pelo fato mesmo que a interação com a presença efetiva das representações produzidas é constantemente exigida.

Palavras-chave: aprendizagem, desenho, escrita, representação.

Abstract: Following Boas, many anthropologists keep considering that learning processes are outside their discipline and fearing that cognitivism is currently using this thema as a tool for annexing anthropology to nativist psychology. After showing that the Chomskyan model internalizes contradictorily the scholar scheme of written grammar and, by reducing learning to a mere "awakening" of internal representations, is actually denying any relevance to actual learning activities, this article focused on two representing graphic activities are through learning processes: writing and drawing. It occurred historically that writing has been systematically transmitted violently by "dressage" ("taming" or "breaking in") and that drawing can be forbidden but not taught in this way for the reason that it is a globally autonomous way of

\footnotetext{
* Contato: alain.pierrot@parisdescartes.fr.
} 
being, as all true learnings are. Drawing is always more than a mental representation since interaction with the actual presence of its'own products is constantly needed.

Keywords: drawing, learning, representation, writing.

Devemos considerar que a aprendizagem é para os antropólogos uma questão intrigante e divisória. Muitos não falam sobre isso, julgam que ela pertence a outra disciplina, à psicologia. São, talvez, os que dão maior importância às aprendizagens, aqueles que afirmam que tudo se aprende e, portanto, que nada é inato, que, paradoxalmente, se interessam menos. Tendo em vista que a criança depende totalmente dos outros, ela não tem efetivamente a escolha da cultura que se impõe a ela de maneira inevitável como sua própria forma de vida. A criança deve aprender tudo sobre sua cultura - e consegue por definição na imensa maioria dos casos, do contrário, não seria cultura comum -, sua aprendizagem se encontra assim, de maneira quase axiomática, totalmente determinada por práticas instituídas, de formas de vida já estruturadas antes dela e independentemente dela. Porém, na maioria das etnografias, as situações de aprendizagem, quando não estão simplesmente ausentes, são geralmente mencionadas somente de modo sucinto. ${ }^{1}$ É seguidamente um detalhe em uma foto e não no texto na qual ela está inserida que nos mostra, por exemplo, que uma criança, que está sendo amamentada por sua mãe, assiste ao sacrifício de uma cabra ou vê mulheres se cobrindo de cinzas, chorando por um morto deitado em frente de sua casa. Como ela não poderia considerar essas práticas como absolutamente necessárias, lógicas, naturais? Heródoto deu uma eloquente ilustração segundo a qual nós mesmos podemos fazer a “experiência do pensamento” por nossa própria conta. ${ }^{2}$ O relativista pode,

1 A questão de saber em que a situação radical das primeiras aprendizagens infantis difere daquela de um adulto estrangeiro no que denominamos, frequentemente, um processo de "aculturação" une-se à questão da aprendizagem do próprio etnólogo que descreve e interpreta uma cultura que não é a sua, mas a questão é tratada, muitas vezes, de maneira implícita através do relato das etapas da integração do estrangeiro ou as da enquete etnográfica, de suas hesitações e de suas descobertas. Foram especialmente os linguistas que avançaram no exame dessas diferenças; elas são, porém, de suma importância para toda a antropologia.

2 No livro III de suas Histórias, Heródoto relata a experiência à qual Dario, rei da Pérsia, teria submetido gregos e, posteriormente, indianos, perguntando que preço seria necessário pagá-los para trocar seus rituais funerários: queimar ou comer seus pais, provocando recusa e desgosto em ambas as partes (Hérodote, 1962, p. 243).

Horizontes Antropológicos, Porto Alegre, ano 21, n. 44, p. 49-80, jul./dez. 2015 
então, parar no intransponível arbítrio cultural e, de acordo com a imagem da "maleabilidade" infinita, da passividade necessária da criança, retomar por sua conta as noções de condicionamento ou de domesticação. ${ }^{3}$

Após Chomsky, os cognitivistas põem radicalmente em dúvida o relativismo e, principalmente, o modelo do "condicionamento" ou da domesticação adotado notadamente pelo linguista e etnólogo Bloomfield nos anos 1920. Será preciso escolher entre essas posições extremas ou adotar uma "de meio termo”? Ao invés de retomar esse questionamento, é um desafio conceitual mais preciso e, penso, mais decisivo, mas ocultado por um debate imensamente de ordem ideológica e metafísica, que o presente texto trata: o do recurso sistemático nas teorias cognitivistas das aprendizagens com representação mental. ${ }^{4}$ A abordagem do "tudo representativo" adotada pelo cognitivismo não busca realmente fazer das aprendizagens seu objeto, porém procura reduzi-los ao status de puros fenômenos de regulamentação, de "aplicação" de dispositivos preestabelecidos. É feito, como penso tê-lo demonstrado (Pierrot, 2014a), levando-o a um esquema teórico, a priori, o da "reescritura", que é tirado de uma forma especial de representação gráfica, o texto. ${ }^{5}$ A convicção dos cognitivistas de que somente representações internas mais profundas podem explicar o que se observa "na superfície” ilustra perfeitamente o que Wittgenstein considerava uma mitologia cientista. Há felizmente outras vias para examinar as aprendizagens sob um ponto de vista antropológico, começando, certamente, pela enquete etnográfica. A enquete se impõe principalmente para integrar plenamente a descrição e a análise dos processos de aprendizagem na antropologia que se baseia sobre o que se observa na superficie para encontrar a lógica das práticas e das situações, e está não somente em conformidade com a lógica da descoberta, mas é igualmente a das aprendizagens, como o demonstraram de maneira convincente Lave e Wenger (1991).

3 Como veremos, essas aprendizagens iniciais se revelam tanto mais conformistas se mais livres, a forma de vida coletiva é evidente e se impõe à criança, inicialmente, sem pressão.

4 Nisso, as teorias cognitivistas não são particularmente originais, mas, ao contrário, se inscrevem na tradição cultural e filosófica dominante desde Kant, onde a representação mental desempenha o papel de atração de um verdadeiro “esquecimento buraco negro” assim que for necessário analisar uma atividade significante, assim que quisermos fornecer uma explicação à formação dos conhecimentos e às aprendizagens e é a duas metáforas, a da imagem e a do texto (os constituintes de base do manual escolar) a que se tem, mais seguidamente, recurso.

5 Johannes Fabian (2006, p. 169) mostra que “o projeto de reescrita” o qual “deixa de lado a concepção técnica propagada por Chomsky” é encontrado nas taxonomias de Lévi-Strauss: “o estruturalismo ‘científico’ é, incontestavelmente aparentado à filosofia hermenêutica e histórica que ele procura ultrapassar e suplantar”.

Horizontes Antropológicos, Porto Alegre, ano 21, n. 44, p. 49-80, jul./dez. 2015 
Foi principalmente em torno de um aprendizado especial, o da linguagem oral, que os modelos teóricos opostos foram formulados, concentrando-se, por iniciativa de Chomsky, na questão da domesticação. Porém, além do debate estreitamente epistemológico sobre o valor explicativo da domesticação, outra questão se impõe: por que a violência, que está, por outro lado, presente sob outras formas nas iniciações, parece inerente à inculcação da escrita? Essa questão diz respeito à antropologia histórica, como Jack Godoy demonstrou magistralmente, vinculando a "domesticação do pensamento selvagem” às teorias da aprendizagem (Goody, 1977). Ele enfatizou, posteriormente, as relações contraditórias mantidas com as representações na maioria das culturas. Esses dois aspectos estão ligados no caso da escrita, que é uma atividade gráfica, uma forma de desenho que se diferenciou por suas convenções específicas da outra atividade gráfica principal que é o desenho figurativo, mantendo com essa atividade de representação relações frequentemente conflituosas. A escrita se diferenciou também do desenho por imposições particularmente fortes em suas modalidades de transmissão, no caso o uso sistemático do chicote e seus equivalentes enquanto que se procurava controlar o poder expressivo e subversivo de representação autônoma do desenho figurativo reputado (ainda hoje, infelizmente...) demasiadamente "livre" e demasiadamente "selvagem", subordinando-o a uma ortodoxia, disciplinando-o pela escola e proibindo-o. A análise de alguns exemplos de aprendizagens gráficas mostra que toda aprendizagem, como aquisição de uma competência, implica um estilo pessoal ao mesmo tempo corporal e social. Entretanto, o desenho corre o risco de continuar sendo uma atividade marginal enquanto não tomarmos consciência do papel exagerado atribuído à representação e à escrita em nossas representações do que seriam as verdadeiras aprendizagens, as aprendizagens "sérias".

\section{Será que a questão da aprendizagem é o cavalo de Iroia do cognitivismo em antropologia?}

Excluir as aprendizagens do campo teórico da antropologia ou, mais seguidamente ainda, negligenciá-las, sem realmente abordá-las, provém, pelo menos em parte, de uma atitude defensiva: o temor de perder seu estatuto de disciplina autônoma. Há um século Boas lutou com toda sua energia e seu talento contra o risco de sua anexação, abrindo valas e erigindo muralhas que 
ele pretendia que fossem definitivamente intransponíveis entre a antropologia cultural e a antropologia física. Porém, ele “deixava as crianças fora”, do campo biológico, como bem demonstram seus artigos sobre o desenvolvimento, exclusivamente considerado em sua perspectiva antirracista através das variações do desenvolvimento físico dos jovens imigrantes causadas pelo seu novo ambiente. Por outro lado, para Boas (2003), "quando um iniciante tenta criar uma obra de arte” isso nos dá informações somente sobre sua "impulsão” e seus "esforços”, ficando fora do contexto antropológico da arte. ${ }^{6}$ Seguindo sua ideia, acreditamos ter "trancado" a independência da antropologia pelo fechamento da estrutura em si mesma, mas essa era, de fato, uma porta fácil de ser empurrada para que entrasse o cognitivismo na antropologia, "cidade aberta" de certa maneira. Realmente, se cada elemento só tem valor ou significação na totalidade de uma estrutura (sintaxe ou social), que ela própria não é dada empiricamente, não seria preciso que ela já estivesse lá, na sua forma geral, para que o indivíduo aprendesse a reconhecê-la em suas diferentes variantes ou versões empíricas? Lévi-Strauss, por essa razão, ligava a antropologia geral à psicologia, estudando a "mente humana", 7 e referindo-se a ele, Chomsky, criador do cognitivismo, fazia o mesmo raciocínio em linguística, e temos boas razões para pensar que "o chomskysmo aplicado mecanicamente à antropologia continua a causar imensos estragos” (Affergan, 2012, p. 220).

Para Chomsky e os cognitivistas, a epistemologia precede e comanda a teoria; partindo de um modelo a priori do que deve ser a teoria procurada para ser legitimamente qualificada de "científica”, é no âmbito da evolução considerada como uma seleção natural dos caracteres adaptativos inatos que eles se interessam pela aprendizagem. Os únicos aspectos das aprendizagens reconhecidos pertinentes são, então, aqueles controláveis experimentalmente através de dispositivos rigorosamente conectados com as demais ciências cognitivas, o que permite deixar de lado as outras "obras" sobre esse tema, ou seja, todas as observações em "meio natural” que não são, portanto, filtradas pela argumentação chomskyana.

Em uma oposição frontal às convicções mecanicistas simplistas associadas ao credo do século XVIII da "toda poderosa educação", a noção da

\footnotetext{
6 Ver Pierrot (2014b, p. 172-173); tentei mostrar o que, sobre esse ponto, opõe Mauss e Boas.

7 "É perigoso pretender ver a antropologia acabar na psicologia cognitiva, como parece afirmar LéviStrauss, após muitas hesitações.” (Affergan, 2012, p. 89).
} 
“aprendizagem por perda” no modelo da surdez fonológica adquirida ${ }^{8}$ foi muito utilizada pelos chomskyanos para se apropriarem do campo da pesquisa sobre as aprendizagens nos anos 1970 . Chomsky se voltou, assim, deliberadamente ao platonismo do saber completo inicial esquecido, mas não apagado, que reaparece mais ou menos com dificuldade pelo que acreditamos ser uma “aprendizagem", mas que não seria senão uma reminiscência. Ele faz questão, efetivamente, de fazer da aprendizagem da linguagem um fenômeno de "reconhecimento" da conformidade das palavras ouvidas pela criança, dos seus próximos, com um modelo interno. ${ }^{9}$ Chomsky não cessou de repetir que as regras verdadeiras não são aquelas que os atores (locutores) acreditam seguir quando eles aprenderam bem a gramática escolar que, por ser demasiadamente superficial, só pode pressupor o essencial, isto é, as "estruturas profundas". É verdade que na maioria das sociedades, para não dizer em todas estritamente falando, adultos e crianças são incapazes de definir as regras de linguagem que eles respeitam, porém, por definição. O que conduz Chomsky, a justo título, afirmar que nossa competência linguística não é um saber proporcional transmissível verbalmente. Ele pensa, então, poder concluir ao inatismo das regras “de reescrita” não adquiridas. Regras inconscientes que somente a ciência consegue desvendar. Penso ter demonstrado ${ }^{10}$ que Chomsky vai bem além de seus precursores platônicos quando considera como inata a essência da linguagem, pois em seu modelo o cérebro se torna um tipo de scriptorium solitário. A transmissão escolar fica, assim, inscrita sob a forma de um "exercício gramatical sem professor" no próprio modelo que a recusa. ${ }^{11}$ Chomsky assimila de fato aprendizagem social, transmissão e ensino, como se não existisse outro modelo de transmissão senão o da instrução oral ou escrita, como se a criança, consequentemente, deveria, de certa maneira, aprender sozinha. Poder-se-ia, por conseguinte, definir o modelo de aprendizagem de Chomsky como um modelo de ensino escolar solipsista, a saber, eminentemente contraditório.

8 Peça central da teoria fonológica que Troubetzkoy forneceu a Jakobson e que ele mesmo a transmitiu a Lévi-Strauss, que por sua vez a tomou como modelo para o que chamamos de estruturalismo...

9 Como Santo Agostinho, na famosa citação que abre as Pesquisas filosóficas onde Wittgenstein (2005) salienta o pressuposto agostiniano que a criança deve saber o que é a linguagem e, especialmente, o que é um substantivo para procurar compreender como as ideias das coisas são “traduzidas” na primeira linguagem humana que ela encontra vindo ao mundo.

10 Ver Pierrot (2014a).

11 O modelo pedagógico subjacente não é o da repetição mecânica, como nas tradições religiosas ou escolares, onde a escrita está ainda subordinada à recitação oral, mas aquele da regra geral colocada a priori como na gramática racionalista de Port-Royal.

Horizontes Antropológicos, Porto Alegre, ano 21, n. 44, p. 49-80, jul./dez. 2015 
De Chomsky retemos principalmente o inatismo, ${ }^{12}$ mas a noção de representação é provavelmente mais crucial, pois é nela que repousa o essencial da abordagem chomskyana: "as regras de gramática são representadas na mente e utilizadas no pensamento e no comportamento... mas, não são certamente acessíveis à consciência” (Chomsky, 1980, p. 123). A representação é uma noção que se adapta a tudo, inicialmente ambígua, ao mesmo tempo física e "mental" em certo sentido, que corresponderia, mais exatamente, à noção implícita. Realmente, uma representação é ou não é explícita, mas ela seria, nesse caso, "inscrita" ao mesmo tempo como traço de memória e saber, de onde a origem do verbo cognite e o uso atual de "cognição” como ato de conhecer "natural e inconsciente” (Affergan, 2012, p. 216).

Se os antropólogos cognitivistas admitem que tudo o que se refere a uma comunidade humana, em oposição a outras, é por definição cultural, e deve ser aprendido, eles concluem que isso deve ser "representado" nos cérebros individuais e postulam que as convergências entre as culturas não provêm da cultura, mas da "natureza" e, baseados no modelo dos linguistas universais chomskyanos, são determinadas por dispositivos inatos que, tornando-os possíveis, ao mesmo tempo, limitam as instituições e as aprendizagens. Tal seria o caso da “teoria da mente” considerada como inata por Maurice Bloch (2013, p. 76): "É a nossa compreensão sobre o que pensamos ser os desejos e as crenças de outras pessoas, bem mais do que podemos ver exteriormente, que informa nossos comportamentos em relação a elas.” É fácil admitir que o bebê imagina que alguém age em função de seus desejos e de suas crenças, mas ele não pensa nisso, ele não sente que os humanos e a mosca que não quer ser capturada e, principalmente, o cachorro que vem aconchegar-se a ele quando está chorando agem em uma relação recíproca. São globalmente seres vivos e não "espíritos" que são vistos como tendo intenções e "estados de espírito”, diretamente visíveis em suas posturas, em seus gestos e em seus olhares. Se a oposição entre o que alguém pensa e o que ele deixa transparecer pode ser considerada como a base da teoria da mente, trata-se de uma "falha". Como Wittgenstein demonstrou, se nós não mentíssemos nunca, não haveria teoria do espírito ou da interioridade. Que a criancinha perceba intenções, desejos e emoções é muito

\footnotetext{
12 “Teríamos uma visão mais clara do que denominamos ‘aprendizagem’, se ela fosse formulada essencialmente como um desenvolvimento de estruturas cognitivas interiormente dirigido, desencadeado e, em parte, somente especificado pelo ambiente.” (Chomsky, 1980, p. 34).
} 
evidente, mas isso é em razão da expressividade infinita do rosto humano, ainda segundo Wittgenstein. Para fazer desta competência uma "teoria do espírito”, é preciso ter previamente promovido a mitologia dualista inscrita em nossa linguagem na categoria de teoria e considerar literalmente expressões como: "nós lemos no espírito" (Bloch, 2013, p. 76), pois é, finalmente, a essa frase clichê retórica que chega o cognitivismo, acreditando, assim, trazer a explicação científica ao fenômeno da compreensão intencional. Quando Maurice Bloch (2013, p. 221), na mesma obra, insiste em lembrar que "nós temos um acesso extraordinariamente rápido e seguro a esse saber”, é novamente em comparação com a consulta de um livro que essa constatação é qualificada como extraordinária. Como destaca muito bem Francis Affergan (2012, p. 229), os cognitivistas "substituem por truques mentais fictícios as conexões naturais com o ambiente”. Trata-se da relação intencional da linguagem com o mundo (de sua "indexicalidade”), mas também da relação do indivíduo com as formas gráficas que ele encontra ou que ele produz cuja presença é irredutível à noção de representação mental, pois justamente quando a intenção representativa se realiza, se concretiza, as representações estão ali "pessoalmente". ${ }^{13}$

Falamos seguidamente de interiorização no sentido de que algo foi realmente aprendido. Esse saber forçosamente interno é depositado na memória. Esse grande livro que pode ser consultado, mais ou menos facilmente, já foi "escrito" no nascimento ou será uma página em branco? A interpretação cognitivista das aprendizagens nos leva a essa imagem do texto interior cuja mitologia está assim inscrita nos jogos de linguagem. Os mesmos equívocos levantados em relação à noção de representação e de cognição se ligam à noção de interioridade à qual está unida outra noção de interioridade: a da relação introspectiva de si. É a mais familiar talvez, inicialmente, percebida como o exame de consciência (culpado); ela é, atualmente, considerada como "construção" de si. Existe, enfim, um terceiro sentido bem menos usual da palavra "interioridade”, aquele explorado por Wittgenstein e que parece particularmente interessante para os antropólogos: trata-se da relação "interna” em sentido lógico ou semântico do termo que conduz necessariamente ao "nós" da linguagem corrente. A ligação lógica ou semântica entre dois enunciados é

13 As pessoas estão em interação constante com suas obras e com todo seu ambiente: como Dewey lembrava, nossa necessidade permanente de alimentação e oxigênio, por si só, faz com que literalmente cada indivíduo vivo seja uma “abstração” por não poder absolutamente ser separado de seu ambiente.

Horizontes Antropológicos, Porto Alegre, ano 21, n. 44, p. 49-80, jul./dez. 2015 
também o que faz que duas pessoas compartilhem do interior de sua linguagem comum, a capacidade para lhe dar uma significação. ${ }^{14} \mathrm{~A}$ aprendizagem de uma linguagem comum como "forma de vida" é um fenômeno tão privado quanto público, que toma sentido em conexão com outras atividades, crenças e necessariamente com elementos relacionais. Para compreender a aprendizagem da linguagem pela criança, como cada indivíduo reconstrói uma língua por sua própria conta, seria necessário fazer o histórico completo de seu percurso, e foi por ter se afastado deliberadamente disso que Chomsky ${ }^{15}$ construiu este abismo infinito entre o modelo interno das estruturas inatas da linguagem e os exemplos considerados “desordenados” da performance.

A criança é bem autônoma em sua aprendizagem da linguagem, mas não age segundo o que Chomsky considera lógico afirmar a priori, como demonstra o exemplo seguinte. ${ }^{16}$ Uma criança de quatro anos, que chegou na França há apenas alguns meses sem conhecer o idioma francês, em uma escola parisiense, recusa ir a um ateliê de colagem onde trabalham prazerosamente outras crianças: "Não quero pintura isso / veux pas peinture çà", esse pequeno exemplo de enunciado situacional comporta múltiplos indícios de aprendizagem; o que é aprendido incontestavelmente é a ordem de base dos elementos da frase francesa, notadamente o uso da negação reduzida à pós-posição do elemento negativo próprio ao francês familiar (sem a negação "não / ne"). É fácil mostrar que as formas verbais acopladas, afirmativa e negativa, são generalizáveis (simplesmente pelo acréscimo de pas): (gosto não / aime pas, caio não / tombe pas, vejo não / vois pas, etc. Poderíamos analisar esse enunciado como a combinação de um sistema de regras formais com simples "variáveis" lexicais. Como, considerando esse exemplo sob este ângulo, explicar o processo de aprendizagem? Para Chomsky, como essas regras certamente jamais foram explicadas à criança, evidentemente, ela jamais aprendeu, portanto, já as sabia. Mas o que nos traz a mais esta explicação "pesada” através de regras sintáxicas profundas em relação à simples generalização de um exemplo significativo? Se voltarmos a esse mesmo exemplo, veremos que um substantivo (pintura) é utilizado como "verbo", regendo o dêitico "isso / çă" (seu objeto),

\footnotetext{
14 Essa ligação “interna” do ponto de vista lógico, semântico e antropológico fica “a crédito” de um ponto de vista radicalmente cético, mas sua alternativa é a do vazio, do informulável.

15 E com ele os procedimentos experimentais, que não podem ser, no melhor dos casos, testes de controle posteriores.

16 Relatei essa observação em Pierrot (2002, p. 130).
} 
contudo são os aspectos de sua própria atividade que contam para a criança, que utiliza a palavra pintura "fora das normas" (como substantivo ou verbo), dependendo do que ela quer significar, a saber, aqui ela recusa uma atividade e mostra que identifica especialmente a cola e a pintura, porque são, aparentemente, duas substâncias com efeitos iguais: sujar-se, ficar com as mãos grudentas ou pegajosas; resumindo, parece uma aversão que compromete sua própria norma de limpeza que está na origem desse "erro de aprendizagem”, ou, mais antes, desse erro-aprendizagem. Imitando, importando a palavra "pintura" a seu ambiente e adaptando-a a seu próprio processo expressivo, a criança faz sistematicamente prova de um poder generativo que não precisa de regras formais que já estão presentes. Todo exemplo sendo generalizável, um único exemplo permitirá o que a regra formal e sua aplicabilidade infinita seria, segundo Chomsky, capaz de "gerar". Por que não buscar os elementos a serem generalizados lá onde eles se encontram, ou seja, na superfície, como em todas as aprendizagens sociais? A aprendizagem da linguagem oral, e como vamos ver também aquela da linguagem escrita, apresenta um interesse teórico especial, o de reinserir essas competências no conjunto das competências humanas ao mesmo tempo corporais e sociais, contrariamente ao que o espiritualismo ou cognitivismo dividem: a crença na existência separada do saber seja ele em uma alma imaterial ou em um “módulo" cerebral especializado.

\section{"Toda aprendizagem é corporal"}

O fato é que não falamos somente de interiorização para significar que nos apropriamos realmente de um saber, mas também, e cada vez mais, de "incorporação". O que inclui tudo o que se diz atualmente do "hábito" e corresponde ao que John Dewey há muito tempo soube restaurar como o que define melhor a experiência e a identidade da pessoa - o costume - à condição de lhe restituir o que o dualismo pensava poder lhe confiscar: a inteligência e a criatividade. Porém, se toda aprendizagem é corporal como é toda a atividade significante, como Malinowski fazia questão de lembrar se inspirando em Dewey, ${ }^{17}$ invocar o corpo em geral sem indicar de que parte do corpo e, principalmente, de que movimento ou de que postura estamos falando, não

17 "Definitivamente, a significação de todas as palavras é completamente resultante da experiência do corpo.” (Malinowski, 1974, p. 297).

Horizontes Antropológicos, Porto Alegre, ano 21, n. 44, p. 49-80, jul./dez. 2015 
nos ensina nada sobre o que caracteriza mais exatamente essa aprendizagem, mas corre o risco de reforçar, contraditoriamente, o dualismo que pretendemos ultrapassar, atribuindo ao corpo, "a seu corpo", vontade, desejo, ação. Realmente, mantemos assim, contraditoriamente, o essencial do dualismo: a distinção entre si e um corpo indiferenciado - abstrato - em uma visão efetivamente "desencarnada" das aprendizagens, cuja atividade real e concreta de aprendizagem está ausente. ${ }^{18}$ Se “o corpo" está envolvido em um saber "intelectual” como a leitura, não é simplesmente porque é preciso olhos para ler, mas porque a própria postura é determinante, dependendo se aprendemos a ler sentados, como no Ocidente, ou em pé, como no caso da caligrafia na China. Gladys Chicharro (2012, p. 170) explica que na China "as crianças aprendem a traçar caracteres como elas aprenderiam passos de dança” e precisam imitar no ar antes de poder reconhecê-los visualmente, mantendo assim com a escrita uma relação muito diferente daquela que nós obtivemos sentados diante de nossos livros. O que aprendemos sentados? A visão estática, que é a de Descartes quando ele se questiona sobre a realidade do chapéu passando "aparentemente" atrás da janela, como a do aluno diante do texto, possui uma natureza "contemplativa". ${ }^{19}$ Isso significa que as posturas de aprendizagem têm realmente uma significação epistemológica, até mesmo metafísica.

\section{Papel crucial da linguagem na classificacão das aprendizagens}

Se a oposição do espírito e do corpo é inutilizável, quais são os principais tipos de aprendizagem sob um ponto de vista antropológico? A etapa descritiva é inevitável, entretanto não podemos fazer um levantamento das configurações que emanam das observações etnográficas e da história (quando ela está suficientemente atenta às formas de vida, isto é, ela mesma etnográfica) sem critérios. O que justifica as categorias, as distinções conceituais utilizadas nas descrições etnográficas das aprendizagens e em suas análises? Numerosos critérios concorrem para tornar os dados significantes, segundo os atores e os observadores e as formas de vida que denominamos as culturas mais ou menos coerentes. Podemos nos reportar à natureza das atividades: visuais, motoras, verbais; à natureza do contexto institucional: iniciação, ensinamento

\footnotetext{
18 E mesmo a moral dualista das “tentações” do corpo, o que levava Dewey a dizer que nossos "hábitos ruins” representam o que somos, porém o que nós recusamos reconhecer.

19 Ver Pierrot (2012).
} 
ou relações informais e, por conseguinte, ao tipo de relações: hierárquica ou igualitária, de cooperação, de coordenação ou tentativa individual; aos campos: do trabalho, do poder, dos ritos, dos jogos, da estética, etc.).

Podemos nos situar em três níveis distintos, sendo o institucional o mais abrangente: como e por que, segundo qual hierarquia dos saberes e dos valores um grupo humano faz questão de transmitir ou impor certas práticas, certos "saberes”? O nível intermediário é o das interações entre as pessoas envolvidas nisso de múltiplas maneiras em relação ao institucional e em função dos seus engajamentos e, enfim, o mais “profundo" e o mais necessário logicamente, aquele da transformação do indivíduo no sentido da aquisição de novas competências. Que essa seja feita de maneira particular ou através de intercâmbios explícitos com um ou “diversos semelhantes”, uma pessoa mais velha, parente, professor especializado, etc., em ambos os casos as competências adquiridas têm absolutamente uma significação social, estão conectadas ou são comparáveis às competências de outras pessoas, estejam elas ou não engajadas nessas interações. O que quer dizer que o nível mais interno dos processos de aprendizagem somente é isolável dos dois outros níveis mais abrangentes pela abstração, o que significa, consequentemente, que o contexto antropológico mais global está envolvido no nível psicológico mais profundo. Essas três dimensões se apresentam sempre simultaneamente envolvidas e interdependentes, mas entram em configurações muito diferentes.

Se considerarmos sob um ponto de vista de conjunto, sinótico, as modalidades de aprendizagem, como Wittgenstein a isso nos conduzia, ${ }^{20}$ encontraremos inevitavelmente a representação escrita. Se ela exerce um papel epistemologicamente decisivo no cognitivismo chomskyano - e, como nós poderíamos tê-lo demonstrado, igualmente nas diferentes correntes hermenêuticas - é em razão do papel central que é o seu, há milênios, nas culturas ocidentais. A "grande divisão" entre o mundo da oralidade e o da escrita é assim uma ilusão de ótica eurocêntrica? O "logocentrismo” que faz da linguagem e, bem mais, da escrita a condição primordial de acesso ao saber foi combatido por Piaget e, atualmente, por todos os movimentos críticos que revalorizam os "saberes do corpo", mas não podemos realmente dar um papel central à linguagem e à escrita? O logocentrismo não é inerente às próprias

${ }^{20}$ Fabian (2006, p. 152) no seu capítulo “O tempo e a escrita sobre o Outro” mostra a que ponto a antropologia é dominada pela metáfora da visão, mas como uma teoria, geralmente, poderia livrar-se do “visualismo”.

Horizontes Antropológicos, Porto Alegre, ano 21, n. 44, p. 49-80, jul./dez. 2015 
teorias que o denunciam precisamente porque são teorias? O risco de ficar sob a influência de um uso normativo implícito da escrita (cuja teoria chomskyana é um exemplo surpreendente) parece-me maior se não fizermos a análise de suas condições de emergência e de transmissão, se não inserirmos as práticas da escrita em seus contextos. Como Jack Goody demonstrou, a escrita pôde desempenhar esse papel, epistemologicamente, por ter previamente obtido uma posição dominante não somente no Ocidente, mas também em outras civilizações da escrita mesmo se essas não conseguiram a mesma posição de hegemonia. Só podemos ver ali uma casualidade histórica, mas o fato é que a escrita representou até agora esse papel de critério principal nas formas de saber, e como nós vamos vê-lo, resultante das modalidades de aprendizagem específicas, pelo menos, é assim que parece ter acontecido.

\section{Educacão formal, escrita e domesticação}

Na maioria dos idiomas a polissemia da palavra "aprendizagem" e de seus equivalentes aproximativos é particularmente ambígua, seria preciso entrar em seus múltiplos “jogos de linguagem gramaticais”21 para ver como se repartem e se interligam as significações dos diferentes substantivos e verbos aparentados, mas só podemos elaborar a hipótese de uma maneira geral, no par, aprender e saber, é o saber que é semanticamente o dominante. ${ }^{22} \mathrm{O}$ saber, por excelência, é o dos livros e principalmente o do Livro. De onde vem o saber depositado nos livros? De uma revelação divina, tal é a resposta muito conhecida das três religiões mediterrâneas monoteístas chamadas, por esta mesma razão, "religiões do Livro". O saber livresco é concebido como uma realidade fora do comum, "sobrenatural”, superior como a Lei imposta do alto, mas essa revelação é, ela mesma, fundamentalmente a palavra de Deus, recebida em sua própria língua humana por um profeta, intercessor entre Deus e os homens; isso dá origem a uma tensão e uma ambivalência nas relações entre a oralidade e a escrita. Essas duas formas de nossa faculdade comum da

${ }^{21}$ Ver Wittgenstein (2005, p. 35-41).

22 Em francês existe uma ambiguidade que outras línguas não conhecem: o verbo aprender tem também o significado de ensinar... é sintomático que a palavra "aprendizagem” tenha substituído a palavra "lição" após as políticas educativas que visam colocar o aluno no centro da atividade pedagógica; fizeram que as mesmas práticas de ensino que se chamavam tradicionalmente "lições” perdurassem, porém são atualmente designadas nos cadernos escolares como "aprendizagens”.

Horizontes Antropológicos, Porto Alegre, ano 21, n. 44, p. 49-80, jul./dez. 2015 
linguagem se rivalizam porque elas dividem uma função essencial: a intenção de mostrar algo. Se há, de fato, no ato da palavra, primordialmente, a intenção de influenciar, a intenção de mostrar algo sob certo ponto de vista, ele participa dessa função instrumental da palavra; de modo muito geral, podemos dizer que temos a necessidade de ensinar no sentido elementar de dizer, o que não pode ser aprendido pela observação dos outros ou pela experiência pessoal; uma função elementar que a linguagem corrente divide com a teoria como "visão" a ser compartilhada. Entretanto, informar alguém em um determinado momento ou lhe "fazer a lição" são atos de palavra que não possuem nem sistematicidade nem autoridade e também não continuidade, características do ensino livresco, seja ele escolar ou religioso.

A transmissão e a aprendizagem da escrita tiveram durante milênios, em todos os continentes, relações complexas e variáveis entre a dominação estatal e econômica, a submissão à lei sacralizada, as crenças e as práticas religiosas ou mágicas, as práticas e os valores educativos, entretanto uma constante se destaca nitidamente: a violência na transmissão da escrita, denominada "domesticação”. Nós a abordamos, no início do texto, como questão epistemológica; é o momento de retomá-la em suas dimensões histórica e antropológica mais amplas que lhe dão sua significação. A violência, no que foi chamado domesticação, não tem somente o sentido de uma forma de dominação mais ou menos brutal, ela tem também um caráter sagrado e, de maneira eminentemente contraditória, o sentido de uma servidão e de um convite elitista para aqueles que constituíram a casta muito restrita dos escribas. ${ }^{23}$ As funções de escrivão (arquivista do poder ou da palavra divina) e de recitante são as principais justificativas de uma atividade que exige uma submissão absoluta à palavra do mestre, mas é, ao mesmo tempo, o meio de se tornar infinitamente superior aos iletrados (entre os quais é preciso contar a própria aristocracia). Eles se apropriam dos segredos mágicos da escrita submetendo-se a castigos corporais e à humilhação tradicionalmente infligidos aos animais domésticos. As batidas com vara nas costas do asno que reiteram indefinidamente o princípio

${ }^{23}$ Existe um grande número de questões abertas, particularmente, aquelas das diferenças e das semelhanças com a iniciação, onde a violência extrema, mas pontual, é exercida nos adolescentes para torná-los adultos; a domesticação é uma violência repetitiva e, portanto, mais “mensurável”, aplicando-se desde a mais tenra idade e que visa a inculcação de uma prática ou de um saber, ao passo que a iniciação só comporta ensinamentos secretos, cujo conteúdo é principalmente simbólico e, por outro lado, não transforma as competências adquiridas.

Horizontes Antropológicos, Porto Alegre, ano 21, n. 44, p. 49-80, jul./dez. 2015 
da obediência absoluta se juntam à convicção de que é preciso gravar, letra por letra, o alfabeto na cabeça, que é um material duro como a pedra...

De milênio em milênio, na Mesopotâmia há quatro mil anos, mil anos no Ocidente e, hoje, nas escolas corânicas, os "letrados" falam sobre as violências recebidas continuamente e sobre o sentimento de superioridade que as acompanhavam. O escritor senegalês Cheikh Hamidou Kane (2011, p. 16) começa sua autobiografia, em 1961, escrevendo sobre a violência de sua educação corânica: "Essa frase que ele não compreendia, pela qual ele sofria o martírio, ele gostava dela pelo seu mistério e pela sua beleza sombria. Essa palavra não era como as outras. Era uma palavra que marcava o sofrimento.” Depois das religiões monoteístas, as escolas nacionais defenderam historicamente a escrita contra a oralidade. As principais características da educação dita formal: a descontextualização dos saberes e da própria linguagem, transformada ou reduzida para ser somente a língua do Estado nacional, a transformação do oral em "leitura”, a didatização dos saberes que as decompõe em programas e, por conseguinte, em sequências, são muito bem conhecidas e, é preciso salientar, a persistência da domesticação na transmissão da escrita.

Salientamos os obstáculos e a passividade obrigatória nas representações e principalmente nas próprias práticas educativas, elas não são forçosamente um impedimento aos processos mais inteligentes de aquisição de competência. Os historiadores Furet e Ozouf (1977) mostraram como, antes da escola, professores pouco letrados alfabetizaram uma boa parte da França, o que prova a eficácia na difusão da leitura e da escrita dos métodos mais rudimentares de transmissão. A “rotinização” tem seu papel em qualquer tipo de desempenho autônomo, sendo a aprendizagem "decorada" talvez a mais evidente, mas lembramos seguidamente também a domesticação no aprendizado musical. O testemunho de Tim Ingold (2013, p. 89) é significativo a esse respeito:

Meu professor [...] colocou minhas mãos sobre o arco e meus dedos sobre a corda de tal forma que eu pudesse, eu mesmo, fazer a experiência de minha relação entre as tensões musculares de minha mão esquerda e os intervalos que disso resultariam. Minha capacidade para tocar violoncelo não me foi transmitida melhor que a minha capacidade de caminhar. Cresci adquirindo-a.

Além das diferenças de estilo pessoal entre os professores indulgentes e outros brutais, Tim Ingold ressalta a inevitável experiência pessoal 
"autônoma” de apropriação da prática, seja qual for a diretividade ou a brutalidade dos controles que podem se exercer sobre ela, como é notoriamente verdade nos casos da escrita. Os professores de dança, guiando seus alunos em seus mínimos gestos e posturas, pressupõem a mesma dinâmica da aquisição deles, como Margaret Mead constatou em Bali nos anos 1930 (Figura 1).

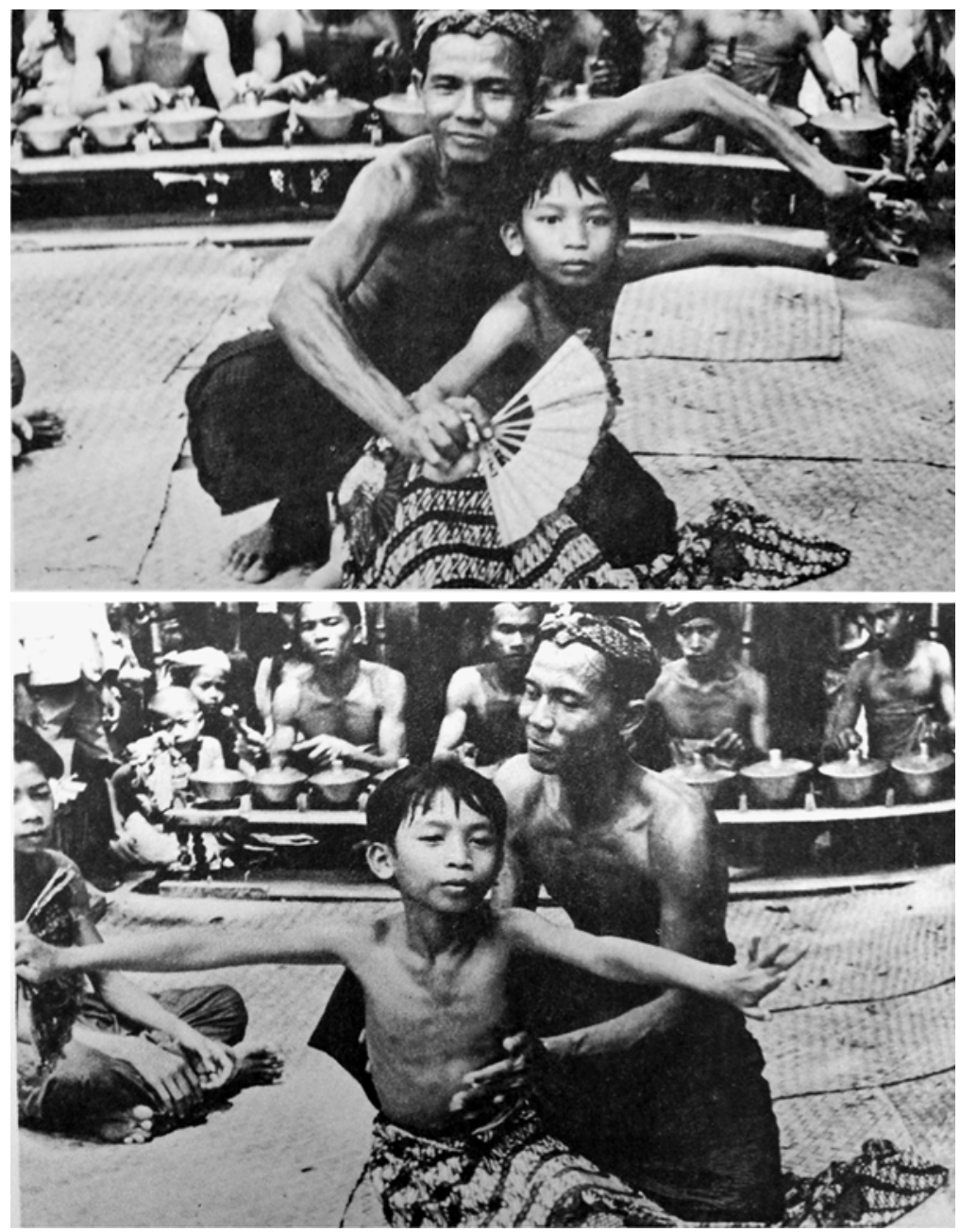

Figura 1. "Mario teaching", Bali, 1936, Plate 17 a, b (Mead, 1964, p. 326-327). 


\section{Educação não formal e "participação periférica legítima"}

Contrastando com "o ato deliberado de ensino nas organizações separadas, [...] nas culturas orais, a aprendizagem é inevitavelmente um processo mais contextualizado, os relatórios ali são menos utilizados” (Goody, 2007, p. 48). Contrariamente à escola, cuja norma exige que a cada etapa seja explicitamente definido o que deve ser ensinado, a impregnação difusa é própria das transmissões chamadas tradicionais, orais ou não formais, onde, para se tornar competente, o aluno deve se virar sozinho: se for autorizado, inicialmente, tentar ajudar ou fazer a mesma coisa que os demais, depois, insensivelmente tornar-se competente como os outros, o que Lave e Wenger souberam qualificar tão bem como "participação periférica legítima”, onde o essencial consiste, de um modo geral, em observar antes de imitar. A aprendizagem pode ser feita através de tentativas autodidatas: não se ensina um bebê a pegar um objeto, quando muito, se estimula, mas a imensa maioria das aprendizagens é acompanhada pela percepção constante dos comportamentos eficientes dos mais velhos que cercam a criança, que ela imita tão regularmente, começando pela linguagem. Uma dimensão decisiva nessa relação perceptiva com os outros reside no caráter intencional das atividades imitadas. O que eles querem fazer, eu também quero fazê-lo, e a imitação se torna, então, global. Lave e Wenger explicam que a ordem da aprendizagem é inversa da ordem de execução do expert: a aprendizagem segue, dessa maneira, do mais global e do mais "superficial” ao mais profundo, ao mais secreto - o domínio das etapas fundamentais da técnica. Seu modelo condiz tanto com as verdadeiras análises da aquisição da linguagem quanto se opõe ao modelo a priori de Chomsky. A "participação periférica legítima” prioriza, assim, a observação em relação à transmissão verbal e a fortiori à escrita e, portanto, à atenção, mas essa pode ser ou não dirigida.

\section{Educacão da atencão, segredo e aprendizagem furtiva}

Quando Tim Ingold fala sobre a educação da atenção, ele encontra a lógica do ensino ostensivo que se inscreve na alternativa "dizer ou mostrar". Santo Agostinho já tinha dado um exemplo prototípico, aquele do adestrador de passarinhos que ensina sem palavras, fazendo unicamente a demonstração metódica de sua técnica:

Horizontes Antropológicos, Porto Alegre, ano 21, n. 44, p. 49-80, jul./dez. 2015 
O adestrador de passarinhos se vendo observado preparava suas varinhas, tendo o cuidado de se mostrar, e ao avistar um passarinho bem próximo, com a ajuda da flauta e do falcão, ele o imobilizava, colocando a mão para que pousasse e o capturava. Esse homem não estaria ensinando aquele que o observa, sem necessidade de sinais através da coisa que este queria saber? (Saint Augustin, 1993, § 32).

Entretanto, muitos relatos, observações e análises insistem, ao contrário, na dissimulação sistemática; por exemplo, Daniel Fabre (etnógrafo do Languedoc) explica que "nem tudo é realmente revelado, o aprendiz deve captar um segredo que lhe é negado... o fabricante de carroças afasta, sob um pretexto qualquer, seu jovem trabalhador no momento em que ele coloca o aro na roda” (Fabre, 1993, p. 241). É também o que Chantal Medaets (2015) observou em sua etnografia de situações de aprendizagem entre os ribeirinhos do Baixo Tapajós na Amazônia; ela insiste sobre o fato de que as crianças aprendem "apesar dos adultos" que nada fazem para facilitarem-lhe a tarefa, sabendo bem que os mais jovens só podem aprender observando-os e tentando fazer o que ainda não lhes é permitido.

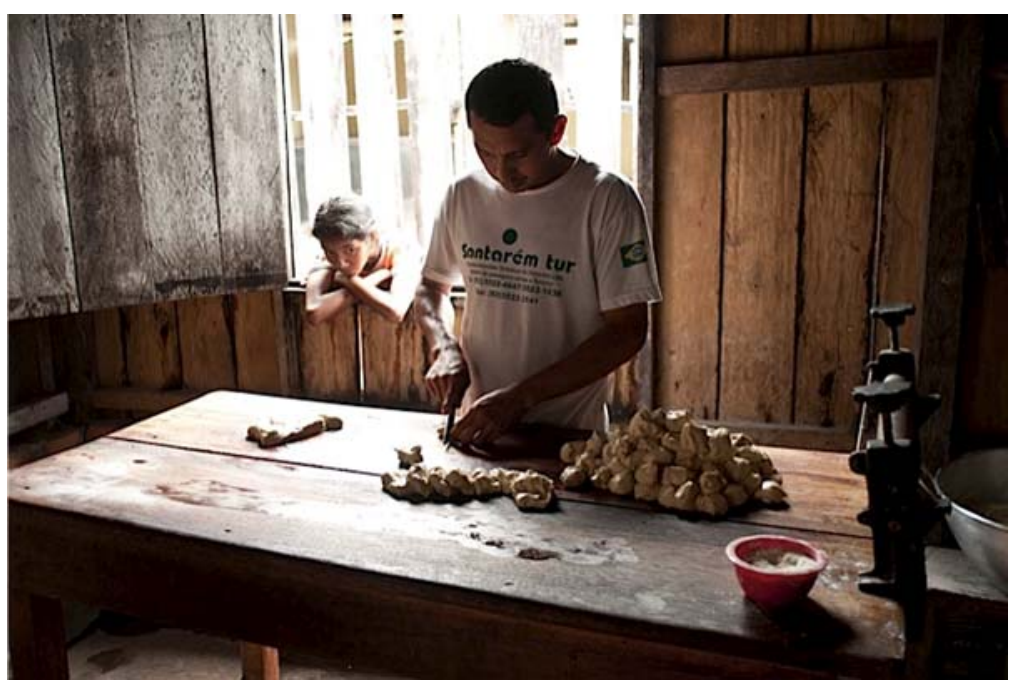

Figura 2. Foto de Lucie Robieux (que trabalhou em parceria com Chantal Medaets no Baixo Tapajós), na qual vemos a jovem Susana que observa o padeiro Márcio trabalhando. Foro tirada em janeiro de 2011. 
A Figura 2 nos mostra Susana, com 15 anos, que observa Márcio, 32, que prepara pão para vender; ele é o padeiro do local e aprendeu a profissão pouco tempo antes, por ocasião de uma temporada passada em Manaus, onde entre outras atividades ele "ajudou em uma padaria”. Uma ajuda, como sempre, que consiste em fazer determinados trabalhos subalternos, "periféricos”, enquanto que o essencial da aprendizagem é feito por uma observação necessariamente furtiva.

Nos dois casos, constatamos que não é por instrução que a aprendizagem é feita, mas se virando sozinho, ou seja, no "silêncio dos mais velhos" (Pierrot, 2012). A prioridade dada assim à percepção pode ser colocada em relação com o recurso também sistemático à "representação” na concepção mentalista da aprendizagem, sendo o cognitivismo a versão modernizada; podemos pensar que a representação mental desempenha aqui um papel sucedâneo da percepção. A quantidade de metáforas da visão para significar o conhecimento vai nesse sentido.

\section{A hierarquia, a iniciação e a relação mestre-disciplina}

A hierarquia está sempre presente, mais ou menos cedo, no contexto das aprendizagens infantis e de todo modo ela se apresenta assim, independente do que possamos dizer, "na mente das crianças”, através da dependência em relação aos adultos e o prestígio dos maiores, daqueles que sabem e a quem se reconhece uma competência legítima. A hierarquia dá uma grande parte de sua significação a essas aprendizagens. Mas a hierarquia não é somente implícita, e, a esse título inevitável, ela é também solenemente mostrada em cerimônias e ritos que comportam sistematicamente violências. É o caso, nas sociedades orais, de iniciações sobre as quais aqui é feita uma alusão rápida, porém uma outra relação hierárquica tem a ver claramente com as aprendizagens, dando um outro sentido à iniciação, a relação mestre-disciplina. Jean Marc de Grave (2012) descreveu e analisou longamente a relação de confiança, de "fidelidade”, de respeito filial que ele observou na iniciação javanesa na casa do “mestre-padrasto”. Em javanês nyantri significa, ao mesmo tempo, aprender e morar na casa do mestre, bem como, na Î́ndia, gurukulam significa "ensino" e "linhagem do mestre". Em culturas onde as tradições religiosas indianas e 
muçulmanas sacralizam também os textos, a relação professor-aluno que se inscreve na duração não fica distante quanto à "participação periférica legítima”. Jean Marc de Grave demonstra assim que entre os modelos extremos de educação formal descontextualizada, dominada pela escrita e a escola, e a educação não formal e suas aprendizagens “furtivas", muitos outros tipos são possíveis.

Onde situar a atividade gráfica figurativa nesse esboço de tipologia das situações de aprendizagem?

\section{A aprendizagem do desenho de Lascaux a Charlie Hebdo}

Embora as atividades gráficas e plásticas sejam reconhecidas há, talvez, mais de 50 mil anos, é surpreendente constatar que a maioria das pessoas diz facilmente que não sabe desenhar do que o inverso, e essa revelação de incompetência teria provavelmente sido partilhada pela maioria de nossos longínquos ancestrais, supondo que eles tiveram direito efetivamente, em sua época, de "visitar Lascaux". ${ }^{24}$ Entretanto, as pinturas e esculturas pré-históricas, que são para nós obras-primas, independentemente de sua função, foram necessariamente feitas por indivíduos com um talento artístico incontestável e que praticavam técnicas sofisticadas. Isso prova que o desenho sempre foi objeto de uma aprendizagem, desenvolvendo em determinadas pessoas somente suas competências gráficas e aparentemente em comparação e em ligação com outras já reconhecidas como competentes.

O desenho é uma competência complexa na medida em que ela integra numerosas dimensões: ele provém da coordenação sensório-motora de maneira exemplar, os gestos a serem coordenados devem todos ser controlados visando o resultado: a impressão visual provocada pelos traços sucessivos dos gestos gráficos. A relação perceptiva do autor com seus próprios "traços” se integra diferentemente conforme os graus de competência gráfica e o estilo pessoal de planejamento e de improvisação no encadeamento desses gestos. Um papel mais ou menos diretor no planejamento é desempenhado

24 Podemos imaginar que pouquíssimos indivíduos tiveram acesso a essas representações escondidas no fundo de grutas como é o caso, mesmo atualmente, há 50 anos... 
pelos modelos estilísticos instituídos. Nós fazemos sempre a diferença entre os desenhos figurativos e não figurativos ${ }^{25}$ mesmo tendo a história da pintura ocidental do século XX complicado muito o “quadro”.

Parece que os usos sociais do desenho figurativo foram, durante muito tempo, limitados à magia e aos rituais (caça, medicina e feitiçaria, cerimônias) e, após conflitos mais ou menos violentos com os iconoclastas, a pintura ocidental foi, inicialmente, uma arte a serviço da religião católica e dos príncipes, por isso existem numerosos ateliês concorrentes na Itália do Rinascimento onde possivelmente a "participação periférica legítima”, tal como foi definida por Lave e Wenger (1991) no caso dos escultores, era também o modo de aprendizagem dos aprendizes pintores, confinados, mais ou menos por um longo tempo, em tarefas subalternas de preparação. Como se tornavam competentes? Seja por filiação seja por “dom”. Os Bellini, Della Robbia, bem como os Brueghel, são exemplos de continuidade artesanal por filiação. Certos artistas dominavam a técnica do ateliê ao saírem da infância, e o casamento de Mantegna parece corresponder muito bem ao tipo nyantri javanês atual do mestre-padrasto (mas é provavelmente verdadeiro, atualmente, na padaria, no açougue ou na farmácia...). O testemunho de Vasari, fundador, dizem, da história da arte é muito instrutivo quanto à oposição das duas aprendizagens "rivais", a da escrita e a do desenho.

Para Vasari o “dom” do desenho é natural, isto é, um presente de Deus, como é demonstrado pelo exemplo do sobrinho de Leonardo da Vinci: "Pierino aprendeu de seu pai os primeiros elementos das letras; mas sem outro mestre que ele próprio, ele começou a desenhar e a modelar na terra de tal forma que ele mostrou que a influência celeste, vista pelo astrólogo e o quiromante, começava a se operar" (Vasari, 2012, p. 138). Este breve exemplo concentra em algumas linhas elementos altamente significativos: é o pai e não o professor de gramática e a violência dos castigos corporais que lhe ensina as letras, ${ }^{26}$ mas é "sem professor" que ele manifesta seu gosto e suas aptidões pela representação gráfica e plástica; quanto a Miguel Ângelo:

25 Incluindo a escrita como representação convencional (secreta ou pública) da palavra.

${ }^{26}$ Como Catão, o Velho ou Durkheim fizeram, eles mesmos, com dois mil anos de intervalo em oposição à pedagogia coletiva repressiva que, por outro lado, eles apoiavam mutadis mutandis a legitimidade. 
Ele foi enviado a estudar com Francesco da Urbino, para aprender gramática; como seu gênio o levava a cultivar o desenho, ele dedicou todo o tempo disponível desenhando, mesmo sendo reprimido e, às vezes, batido pelo seu pai e pelos mais velhos, que consideravam, talvez, esta atividade, que lhes era desconhecida, como algo vil e indigno de sua antiga casa. (Vasari, 2012, p. 348).

As caricaturas que Fra Filippo Lippi fazia nos manuais escolares são ainda mais significativas, tornando-o “culpado”; órfão pobre, ele foi confiado aos 8 anos às carmelitas:

Quanto mais propensão ele demostrava para as obras de habilidade, maior era sua repugnância e aversão pelo estudo das letras. Foi colocado com os demais noviços sob a disciplina do professor de gramática, para ver o que ele poderia fazer; mas ao invés de estudar, ele se divertia cobrindo de bambochatas ${ }^{27}$ seus livros e os de seus colegas. $\mathrm{O}$ prior do convento decidiu, então, dar prioridade à sua inclinação para a pintura. (Vasari, 2012, p. 40).

A atitude dos príncipes da Igreja na Itália do Renascimento é iconófila, o que explica a decisão compreensiva de utilizar a diversidade natural (e, portanto, divina) dos talentos. ${ }^{28} \mathrm{O}$ desenho comporta uma dimensão de prestígio através da perspectiva profissional da pintura oficial da Igreja e dos príncipes, mas permanece "subversivo" em relação à escrita. Terminarei as citações de Vasari (2012, p. 23-24) com o exemplo de Giotto:

Aos 8 anos [...] [seu pai] Bondone lhe deu algumas ovelhas para cuidar, ele as levava nos campos para pastarem; mas conduzindo-as em diferentes lugares, ele desenhava na terra, na areia ou nas pedras lisas, como impelido por uma inspiração para desenhar os objetos que ele via e as fantasias que lhe passavam pela cabeça. Um dia Cimabue [...] encontrou Giotto. Enquanto seu rebanho pastava, ele desenhava com um cascalho pontudo uma das suas cabras, numa

27 Essa palavra erudita designa principalmente cenas pitorescas ou grotescas; no texto original encontramos a palavra fantocci; fantoccio significa geralmente "boneco" (por exemplo, "boneco de neve”) ou "manequim” e igualmente bamboccio, boneca.

28 A comparação com os pintores letrados e geômetras que foram Piero della Francesca e Alberti, o teórico da perspectiva e da linha reta, mostra que a oposição entre o desenho e a escrita por mais radical (e mesmo violenta) que possa ser e ainda possa continuar a ser, pode perfeitamente ser ultrapassada e se harmonizar, e tudo como o “rebelde” Lippi se volta à ortodoxia albertiana.

Horizontes Antropológicos, Porto Alegre, ano 21, n. 44, p. 49-80, jul./dez. 2015 
pedra lisa e polida tendo somente a natureza como mestre e, então, lhe pediu para segui-lo $[\ldots]$

Essa estória não parece vir de uma lenda, Vasari não diz o mesmo sobre todos os pintores e faz questão de sublinhar que Beccafumi, dois séculos mais tarde, manifestou suas tendências para o desenho da mesma maneira que Giotto. Eu mesmo recolhi histórias realmente parecidas às de Vasari de artistas senegaleses contemporâneos famosos ou “desconhecidos” (Pierrot, 2014b, p. $176-177){ }^{29}$

Certas sociedades, por outro lado, sob a influência especialmente do Islã (mas também foi o caso do puritanismo protestante como muito bem mostrou Jack Goody), reprovam uma atividade que visaria a rivalizar com o “criador”, uma reprovação ${ }^{30}$ cuja consequência é o empobrecimento do meio gráfico e das atividades gráficas, assim acontece com os peuls do Senegal Oriental. Vou comparar dois indivíduos para tirar, assim, algumas consequências sobre a aprendizagem. Um jovem de 15 anos e uma criança de 10, em 1979, e essa mesma criança em 2013 e 2014, então com 45 anos. O jovem pastor de 15 anos, passando de um desenho para outro, ultrapassou em alguns instantes as etapas (Figura 3) que Luquet, há um século, definiu

${ }^{29}$ Comparando com o resto da África Ocidental, o contexto senegalês é, de início, graficamente pobre, mas não há interdição da representação em si mesma como testemunha a onipresença das imagens de santos muçulmanos que proliferam nos muros do bairro da Medina, da autoestrada urbana, das lojas e ônibus de qualquer estilo e de qualquer época e, até mesmo, nos troncos das árvores. Trata-se, nesse caso, de "imagens religiosas" tão iconófilas quanto a tradição católica.

${ }^{30}$ Em Paris, no dia 7 de janeiro de 2015, dois irmãos, órfãos, assassinaram, não muito longe de minha casa, os desenhistas de Charlie Hebdo. Esse massacre testemunha a violência paroxística à qual podem conduzir as frustrações e o ódio acumulados "em nossas periferias" quando ela é canalizada contra as caricaturas "blasfematórias". Lembro-me que 30 anos antes - na época do nascimento desses dois assassinos - numa cidade dos arredores de Paris julgada difícil, um aluno, ele também "um caso social” e que perturbava a escola, metamorfoseou-se, apaixonando-se por um quadro de Rafael do Museu do Louvre que começou a copiar todas as semanas; toda proporção mantida, era um exemplo de rebelde tipo Filippo Lippi no sentido em que a atividade gráfica era, para ele, uma valorização e um reconhecimento de suas competências, ao passo que os irmãos Koachi, os matadores de Charlie Hebdo, tinham aprendido a ver ali uma atividade que representava um sacrilégio e, principalmente, o desprezo de sua própria identidade muçulmana. Ilustração trágica da ambivalência das representações salientadas por Jack Goody.

Horizontes Antropológicos, Porto Alegre, ano 21, n. 44, p. 49-80, jul./dez. 2015 
como estágios na evolução psicológica da criança e da humanidade (Luquet, 1977, p. 177). ${ }^{31}$ É em interação imediata com seus próprios desenhos que ele transpõe essas etapas cognitivas, que são as de sua atividade intencional (um perfeito exemplo do learning by doing, como com a bicicleta tal como se serve dela (Figura 4).

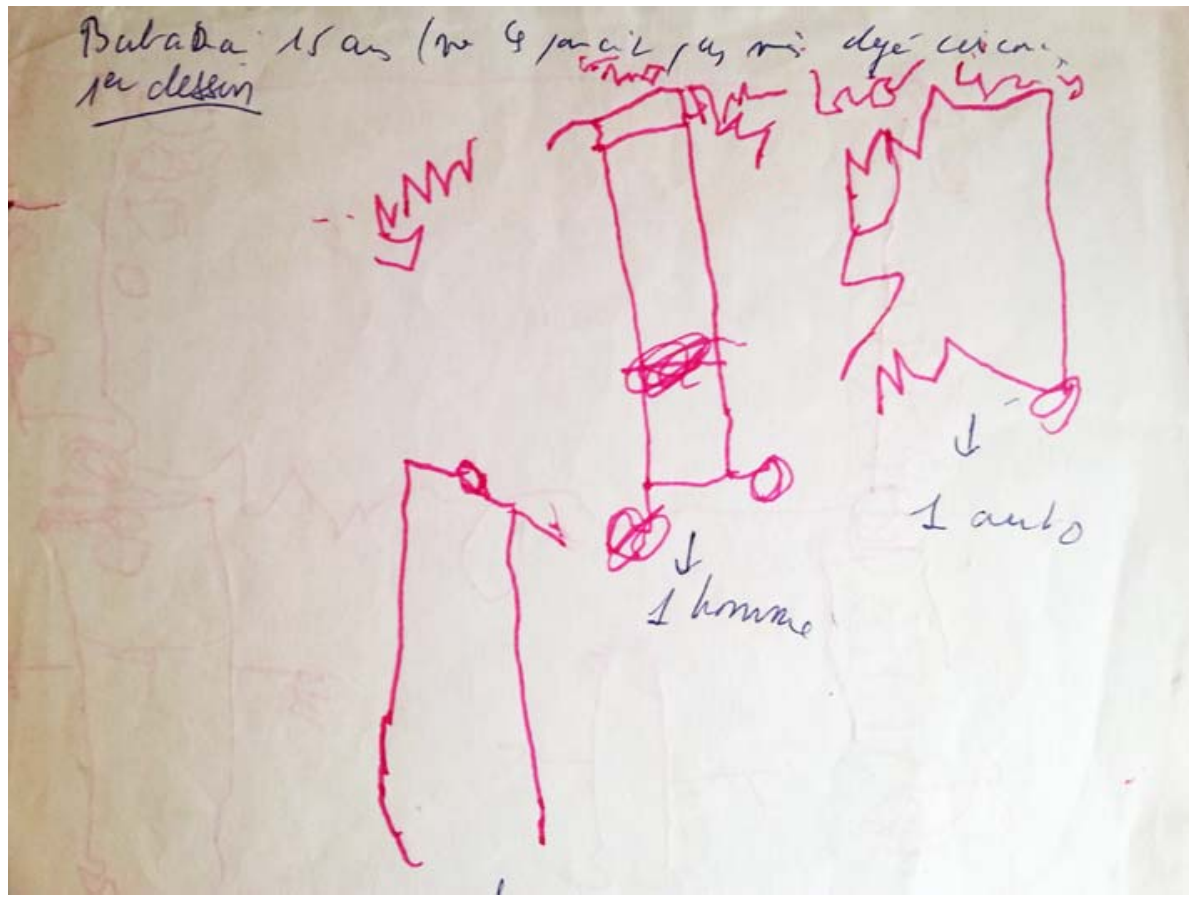

Figura 3. Em 1979, Bubakar, pastor de 15 anos, desenha pela primeira vez (mas ele já aprendev a escrever em árabe). Vemos que a verticalidade é a primeira característica humana, em seguida, a forma humana e a do carro são desenhadas de maneira similar, mas a cabeça do homem está em cima (do torso retangular e diante do carro do lado esquerdo), o que no desenho seguinte é mais reconhecível: no meio do corpo os curativos revestem 0 sexo após a circuncisão.

31 Encontramos ali todo o equívoco da analogia evolucionista entre os desenhos primitivo, pré-histórico e infantil.

Horizontes Antropológicos, Porto Alegre, ano 21, n. 44, p. 49-80, jul./dez. 2015 


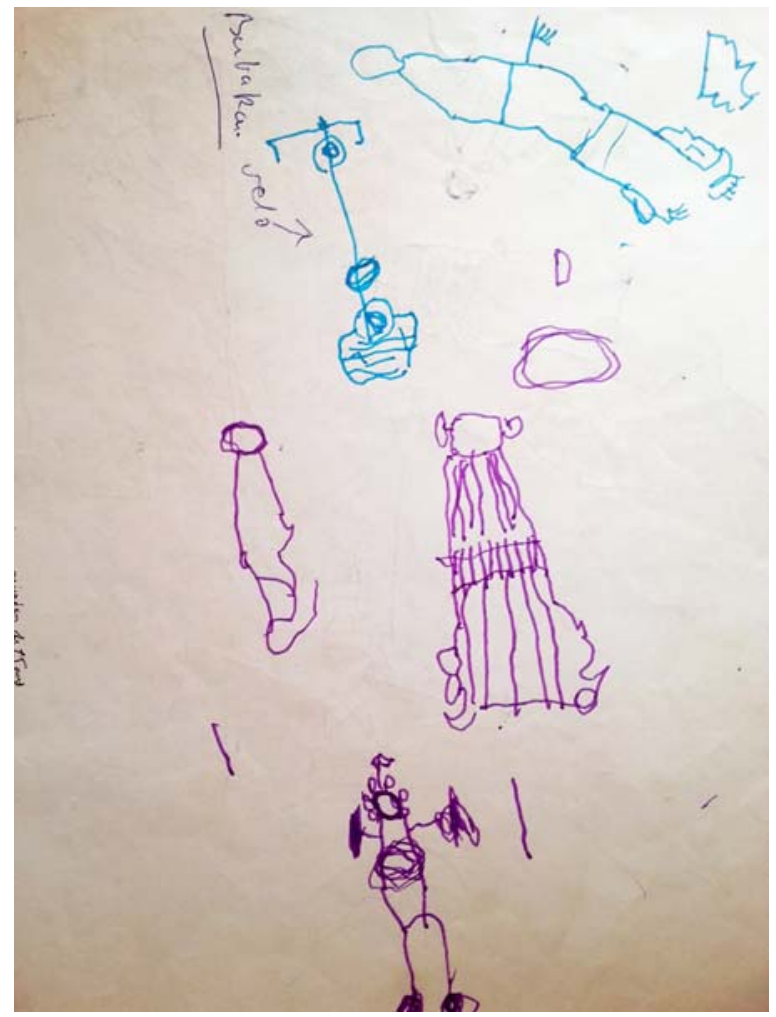

Figura 4. Em seu segundo desenho (1979), Bubakar desenvolve a estrutura "normal" do corpo humano e desenha de maneira muito realista uma "máscara" cerimonial (na metade direita da página) cobrindo a cabeca com uma touca tapa orelhas $\mathrm{e}$ o corpo com uma túnica que vai até os pés. Ele desenha também (na parte de cima) uma bicicleta tal como a usamos, o que parece bem atestar a falta de familiaridade com a representacão usual da bicicleta de perfil.

Gano Kébé, de 10 anos, produziu 16 desenhos (mais que a totalidade dos desenhos dos outros meninos da povoação), em 1979 (Figura 5). Apesar de sua força expressiva, eles não mudaram em nada sua vida, pois, contrariamente a Giotto, ele não encontrou seu Cimabue pela simples razão que não existia em seu meio. Ele me disse recentemente que continua desenhando, mas simplesmente para ele, e sua temática particular parece aproximar-se de certos mitos peuls, associando serpentes ao gado, mas ele não reconhece isso naturalmente (Figuras 6, 7, 8). 


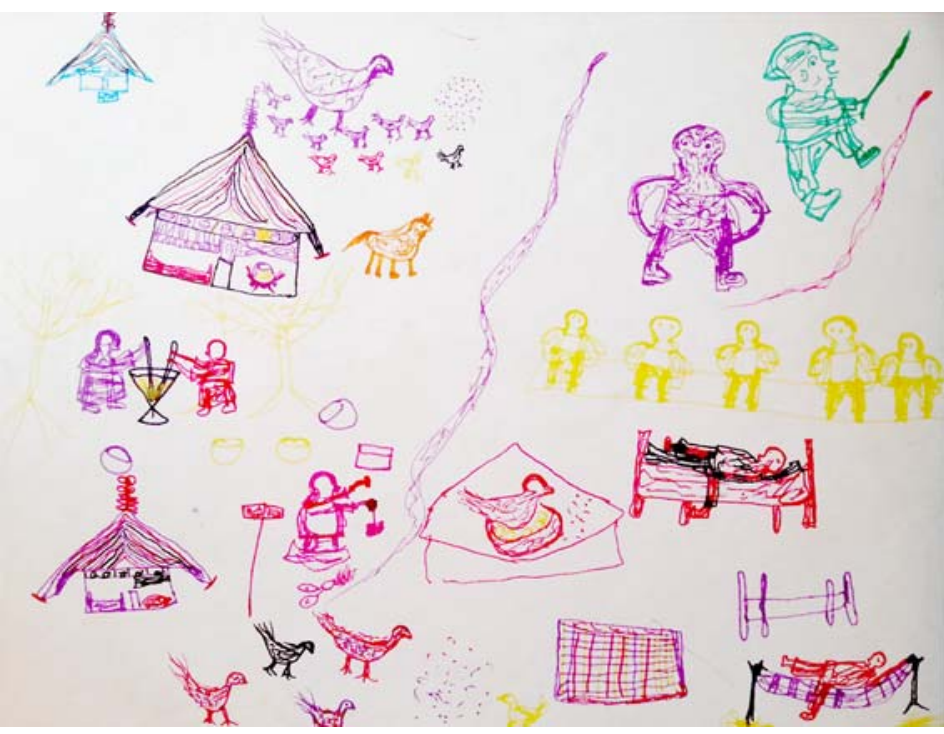

Figura 5. Gano Kébé (10 anos em 1979) em uma série de desenhos descreve sistematicamente a vida em sua aldeia; aqui, à esquerda da grande cobra central, as atividades das mulheres e da ferraria no meio das galinhas, de um quadrúpede com chifres, certamente uma vaca, e casas com celeiro; à direita, homens, um deles deitado em uma rede ao lado de uma galinha que está chocando enquanto que uma outra está cacando uma cobra; os alunos estão sentados em um banco da escola (as casas com celeiro e as ferramentas depois sumiram).

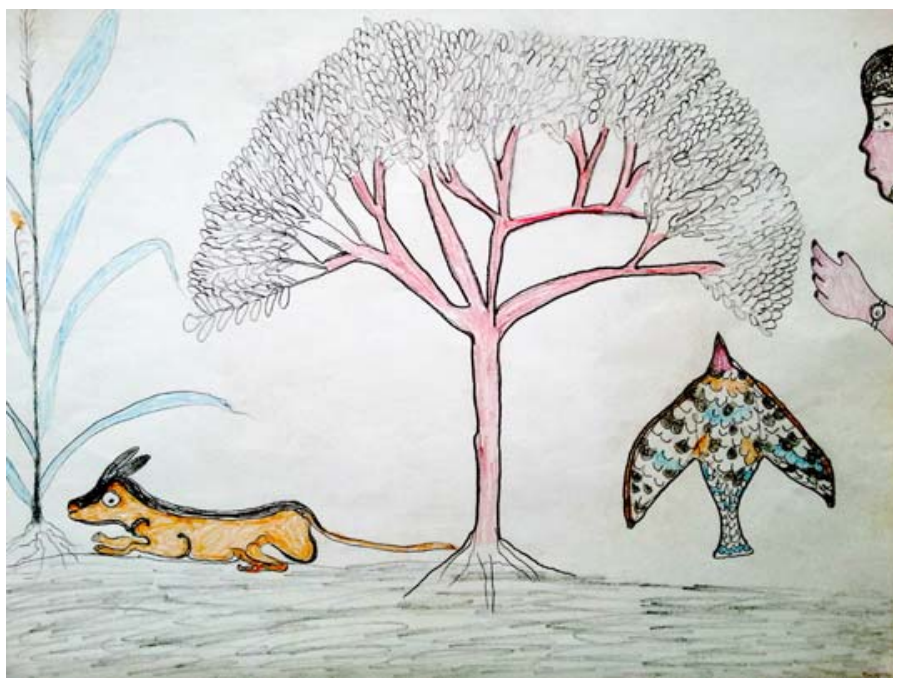

figura 6. Em 2013, Gano Kébé (45 anos) realiza composicões aparentemente mais misteriosas, sobre as quais dá uma interpretacão muito prosaica; aqui o cachorro do proprietário, que podemos ver à direita (com seu relógio), se prepara para pular sobre um macaco que veio roubar os grãos de milho (conteúdo de um outro desenho).

Horizontes Antropológicos, Porto Alegre, ano 21, n. 44, p. 49-80, jul./dez. 2015 


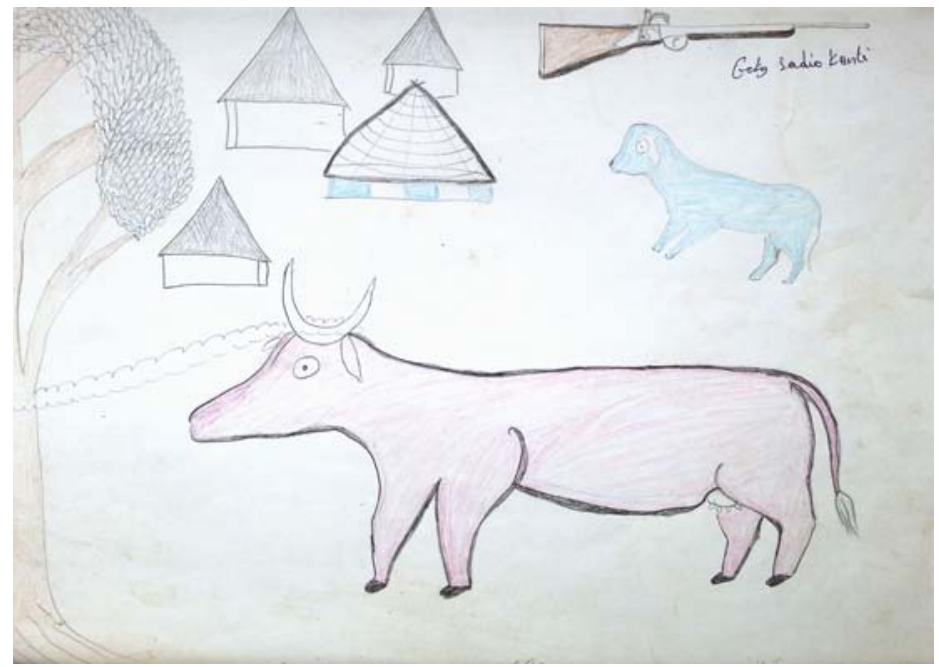

Figura 7. Gano Kébé, em 2013, agora ele mesmo é proprietário de alguns animais, desenha seguidamente bois (comparar com a vaca/galinha da Figura 5); os outros elementos, como a correia que mantém a vaca amarrada na árvore, o cachorro, a espingarda e as casas, são sua propriedade.

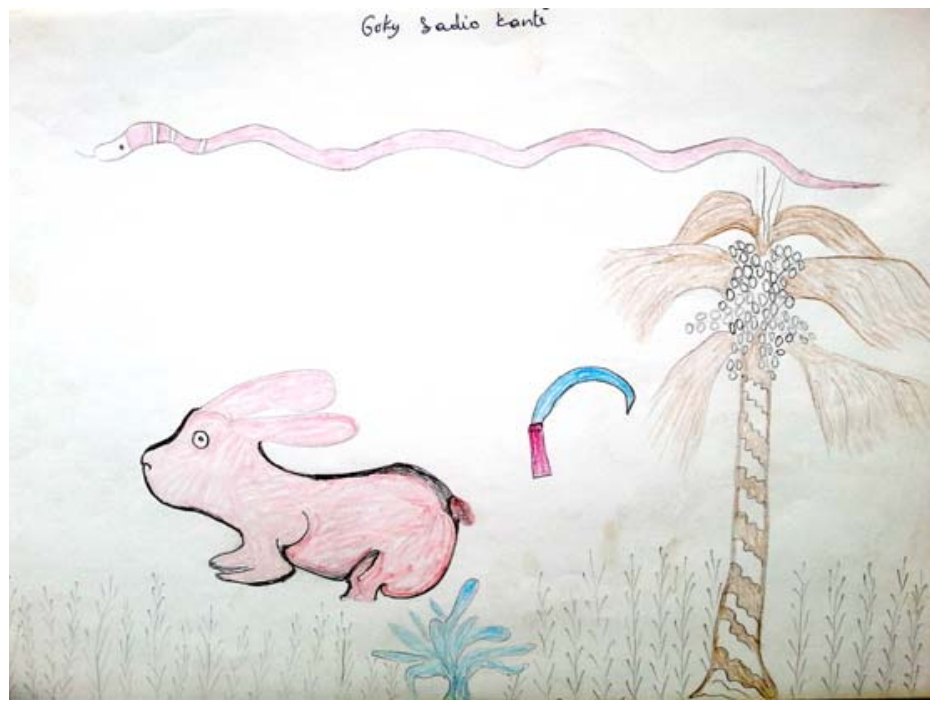

Figura 8. Em 2013, Gano Kebé explica que o camponês, ao ver a cobra e um coelho ao mesmo tempo, tem medo e escapa, abandonando sua foice perto do coqueiro.

Horizontes Antropológicos, Porto Alegre, ano 21, n. 44, p. 49-80, jul./dez. 2015 


\section{A escolarizacão do desenho}

O desenho foi submetido a diversas formas de "domesticação" pela escola, seja subordinando-o à escrita como prática para o domínio das formas elementares: retas e curvas, seja generalizando estereótipos gráficos especiais como o "torso islâmico" (Pierrot, 2014b, p. 180), o que é uma forma de escrita segundo Mauss, seja ainda submetendo-o à norma estilística do realismo visual, seguindo o modelo que se vê através da "janela” retangular da folha ou da moldura cujas bordas cortam necessariamente os elementos representados assim que saem da moldura. Uma norma que encontramos, por exemplo, nos desenhos de uma escola guarani que tive a ocasião de observar no mês de maio de 2014. Trata-se de uma ocidentalização da forma, embora o conteúdo por suas temáticas seja “oficialmente” aquele do reconhecimento identitário (Figura 9), mas um dos jovens desenhistas guarani soube também utilizá-lo de maneira humorística conforme o retrato que fez de mim (Figura 11) no verso da folha onde figura o desenho esperado: o da aldeia tradicional guarani (Figura 10).

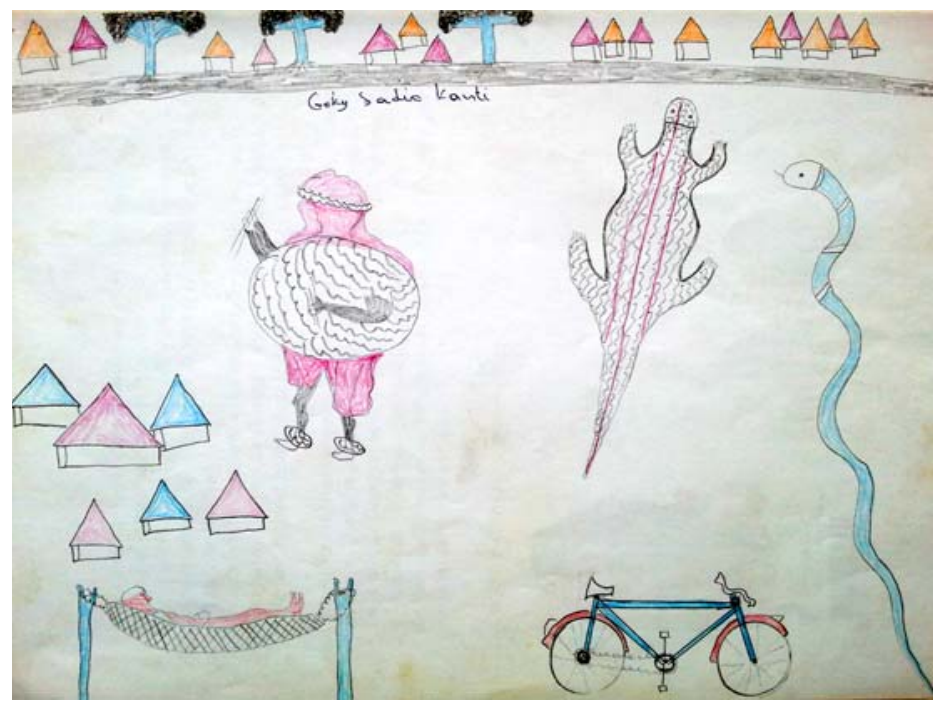

Figura 9. Em 2013, encontramos novamente os elementos habituais desenhados por Gano Kébé desde sua infância: casas, rede, como em outros desenhos recentes, a galinha e seus pintinhos, a mãe escorpião e seu filhote e, seguidamente, uma cobra, aqui ao lado de uma lagartixa (o desenho da bicicleta deve ser comparado ao segundo desenho de Bubakar, de 1979, na Figura 4). 


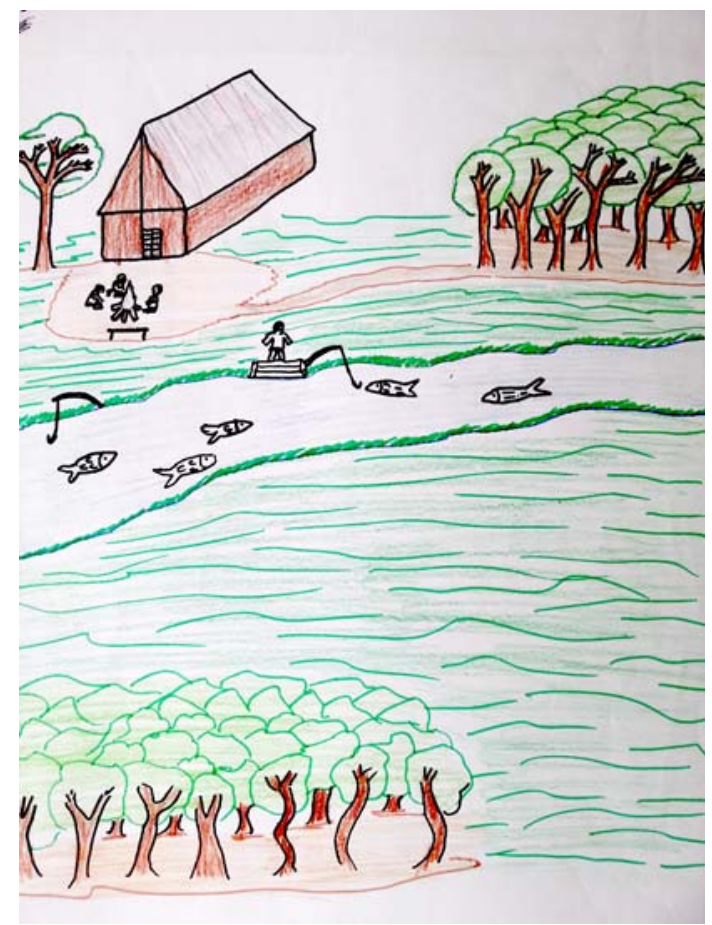

Figura 10. A aldeia guarani tradicional.

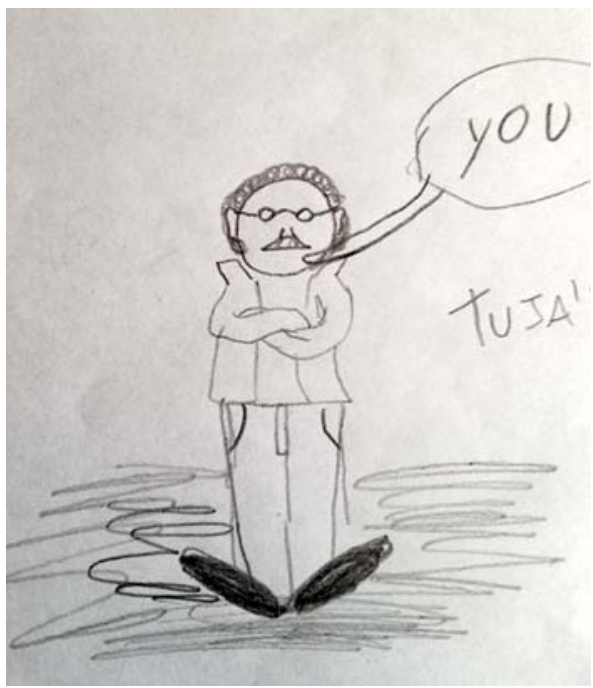

Figura 11. Depois de ter desenhado a aldeia guarani tradicional, como os demais alunos, o jovem desenhista guarani se voltou para o "visitante".

Horizontes Antropológicos, Porto Alegre, ano 21, n. 44, p. 49-80, jul./dez. 2015 
A aprendizagem do desenho mostra, assim, o que é verdadeiro em todas as aprendizagens, a saber, são sempre transformações de competências em um desenvolvimento individual, em uma experiência ao mesmo tempo corporal e social global onde o gesto e a percepção se organizam para produzir um estilo individual. Essas transformações tomam seu sentido em uma história pessoal através das relações de identificação, segundo diferentes modalidades de interação, e a interação com seu meio humano (domesticação, aprendizagem furtiva, relação professor-aluno) e com os produtos de sua própria atividade. Se houver representações essas não são senão um elemento nos esquemas de ação que são as competências em via de apropriação, e quando elas são centrais, como em um relato ou um desenho, elas serão "mentais" somente se forem ou puderem ser perceptíveis. Mesmo quando as imagens mentais e as visões oníricas desempenham ali um papel incontestável, a aprendizagem do desenho é irredutível às representações mentais porque ela provém de sua própria atividade de produção, da interação com seu "produto" cuja presença efetiva é objeto de uma experiência subjetiva, emocional tanto para o autor quanto para os outros. Um estilo pessoal se desenvolve de maneira bem mais singular por se afirmar a partir de postulados e técnicas compartilhadas na forma de vida comum de um ateliê ou de outras formas de "comunidades de aprendizagem” equivalentes. Por ser uma atividade efetiva de representação, o aprendiz - como o professor - se confronta diretamente com a hierarquia de valores e com as normas sociais. É por todas essas razões que a aprendizagem do desenho pertence eminentemente à antropologia e, contrariamente à oposição radical apresentada por Boas entre a arte e a aprendizagem, ele está bem mais próximo das transformações, das importações e dos "arranjos" culturais que vivenciamos; ele não é senão um momento em uma história pessoal e coletiva ainda inacabada.

\section{Referências}

AFFERGAN, F. Le moment critique de l'anthropologie. Paris: Hermann: 2012.

BLOCH, M. L'anthropologie et le défi cognitiviste. Paris: Odile Jacob, 2013.

BOAS, F. L'art primitif. Paris: Adam Biro, 2003. 
CHICHARRO, G. De la gymnastique à l'art graphique. Apprentissage et enseignement dans les écoles élémentaires chinoises. In: GRAVE, J.-M. de (Dir.). Dimension formelle et non formelle de l'éducation en Asie orientale: socialisation et rapport au contenu d'apprentissage. Aix-en-Provence: Presses Universitaires de Provence, 2012. p. 157-177.

CHOMSKY, N. Règles et représentations. Paris: Flammarion, 1980.

FABIAN, J. Le temps et les autres: comment l'anthropologie construit son objet. Toulouse: Anacharsis, 2006.

FABRE, D. Le livre et sa magie. In: CHARTIER, R. (Dir.). Pratiques de la lectur,. Paris: Payot, 1993. p. 231-263.

FURET, F.; OZOUF, J. Lire et écrire: l'aphabétisation des Français de Calvin à Jules Ferry. Paris: Editions de Minuit, 1977.

GOODY, J. La raison graphique. Paris: Les éditions de Minuit, 1977.

GOODY, J. Pouvoirs et savoirs de l'écrit. Paris: La dispute, 2007.

GRAVE, J.-M. de (Dir.). Dimension formelle et non formelle de l'éducation en Asie orientale: socialisation et rapport au contenu d'apprentissage. Aix-enProvence: Presses Universitaires de Provence, 2012.

HÉRODOTE. Histoires. Paris: Les Belles Lettres, 1962.

INGOLD, T. Marcher avec les dragons. Le Kremlin-Bicêtre: Zones sensibles, 2013.

KANE, C. H. L'aventure ambiguë. Paris: 10/18, 2011.

LAVE, J.; WENGER, E. Situated learning: legitimate peripheral participation. Cambridge: Cambridge University Press, 1991.

LUQUET, G.-H. Le dessin enfantin. Paris: Delachaux et Niestlé, 1977.

MALINOWSKI, B. Les jardins de corail. Paris: François Maspero, 1974. 
MEAD, M. Continuities in cultural evolution. New Haven: Yale University Press, 1964.

MEDAETS, C. Aiguiser son regard: apprendre à apprendre sur les berges du Tapajós. Cargo: Revue Internationale d'Anthropologie Culturelle et Sociale, Paris, n. 3, p. 79-96, 2015.

PIERROT, A. Grammaire française de l'intégration ou jeu de langage et mythologie. Paris: Fabert, 2002.

PIERROT, A. Le silence des aînés. In: GRAVE, J.-M. de (Dir.). Dimension formelle et non formelle de l'éducation en Asie orientale: socialisation et rapport au contenu d'apprentissage. Aix-en-Provence: Presses Universitaires de Provence, 2012. p. 7-25.

PIERROT, A. Compétence, oralité et écriture. In: BORNAND, S.; LEGUY, C. (Dir.). Compétence et performance: perspectives interdisciplinaires sur une dichotomie classique. Paris: Karthala, 2014a. p. 237-264.

PIERROT, A. Le dessin, forme élémentaire de la vie esthétique - un terrain africain. In: DIANTEILL, E. (Dir.). Marcel Mauss, en théorie et en pratique. Paris: Archives Karéline-Éditions du Sandre, 2014b. p. 163-191.

SAINT AUGUSTIN. Le maître, le libre arbitre. Paris: Institut d'Etudes Augustiniennes, 1993.

VASARI, G. Vies des artistes: 2. Paris: Grasset, 2012.

WITTGENSTEIN, L. Recherches philosophiques. Paris: Gallimard, 2005. 